\title{
Deregulation as an Agent of Globalization: A Case of Broadcasting Media in Nigeria
}

\author{
Enyia Charles Daniel \\ (ACIPM, HRPL) \\ Department of Management, \\ University of Port Harcourt
}

\author{
Peterside Godwin Dodd lyowuna \\ (Ksc, FNIM) \\ Department of Management, \\ University of Port Harcourt
}

\begin{abstract}
This work looks at the deregulation in the Nigerian economic sector and more especially in the broadcasting media subsector considering its introduction from the Ibrahim Babangida administration to the present day civilian government. It considers the extent to which deregulation has attracted globalization which in turn has affected cultural practices and behaviors in Nigeria, it has also considered how the proliferation radio and TV stations have led to indecision by viewers who now find it difficult in choosing a particular station for a long time.
\end{abstract}

\section{Keywords}

Deregulation, Globalization, Broadcasting

\section{INTRODUCTION}

According to [1], Globalization can be defined as the drive to move beyond national frontiers. [14] further asserts that it is a process whereby cultural, economic, social, political, legal and technological relations increasingly takes place on a global scale. It can be seen as a structuration of the world in its totality. [13] is also of the opinion that globalization is a process of creating a global/international market in which all nations are forced to be a part of. It is a general belief that those nations who do not take part in the business of globalization would find themselves becoming obsolete in the scheme of things and this would make the entire citizens and process become impoverished. In simple term, [5] defines globalization as the intensification of worldwide social relations which could bring different localities closer to events in diaspora and vice versa. The term globalization is derived from the word "'globe" which can be interpreted as "worldwide". This globalization has its influence on various sectors of the Nigerian economy and the media as a sub-sector is not left out. Globalization can be traced to the change in political activities in Europe which also included the fall of the Berlin wall as well as the emergence and growth of the World Wide Web [13]

Deregulation on the other hand is an economic reform which involves both monetary and fiscal policy measures whereby the laws which hinder market entry and exit are minimized or removed totally in order to enhance the competitiveness of the activities of that nation's economy [7]. [1] further believes that the term deregulation can be seen as the privatization, marketization as well as diversification of a nation's economy. This simply means the participation of private investors and not just government alone in running the activities of such enterprise. Deregulation ensures an economic environment that is competitive in nature which is free from monopoly and allow the economic principle of demand and supply to prevail. In Nigeria, the idea of deregulation was first introduced in 1986 by the General Ibrahim Babangida led military administration but the implementation was not successful and this made it difficult for the General Abacha administration to continue with it [1]. However, the move towards deregulation was further reintroduced by the Abdusalami Abubakar regime (19981999) and was further facilitated by the Olusegun Obasanjo led civilian government. It was Obasanjo who we can say brought deregulation to lime light in Nigeria [5]

Broadcasting in Nigeria was introduced first in 1932 when England sent its first radio signal to Nigeria [2] During this period, radio broadcasting began with wired broadcasting which was also known as Radio Distribution Service (RDS). With this form of broadcasting, programs were aired using which were been connected to loud speakers and subscription fees were paid by homes that were connected. One issue that characterized the existence of existence of broadcasting in Nigeria was the fact that it was solely controlled by the government without of private organization and prior to 1992 , the state government owned television stations were limited to broadcasting through Ultra Hugh Frequency (UHF) while only the federal government owned station (NTA) was permitted to use Very High Frequency (VHF). The deregulation of broadcast media formally began in 1992 with the establishment of Nigerian broadcasting commission (NBC) by the Ibrahim Babangida military regime and ever since, there have been an establishment of over 15 private radio and TV companies [9]

This study would however investigate the extent to which deregulation in the broadcast media has really acted as an agent of globalization in Nigeria.

\section{PROBLEM OF THE STUDY}

Today, it is believed that with the proliferation of the broadcast media in Nigeria, the business of broadcasting in Nigeria have become more dynamic, pervasive as well as open to the trends of globalization. However, it has also made citizens put away some fundamental cultural values which defines who they are and where they are coming from [9] Today, there is a wide range of options available to viewers and this have also contributed to psychological trauma of indecision owing to the desirability of every option selected [10]. Today, Lagos alone have a constellation of 33 radio and television stations, 5 micro wave distribution systems and one direct satellite television which altogether broadcasts 55 channels to the public and this has also made the monitoring activities by NBS more difficult as it lacks the required manpower and technology to carry out such function. The quest for profit which is also an underlying reason for the establishment of broadcast stations by individuals and groups have made them put whatsoever image on air in the name of 
broadcast. We see nudity on the rise these days especially among teens and adults as a result of what they have seen on their TV screen. We see kids dancing in birthday parties like they are adults and this have made it very difficult to differentiate teens from adult these days. The high rate of crime and other illegal activities by youths can also be attributed to the proliferation of video contents which are not supposed to be viewed by such age and today, broadcast stations spend less time on educating viewers and more time in entertaining them which has led to juvenile delinquency and other related anomalies in Nigeria. It is on this backdrop that this work would consider the extent to which deregulation of the broadcast media in Nigeria have acted as an agent of globalization.

\section{OBJECTIVE OF THE STUDY}

The objective of this work is to examine the extent to which deregulation has acted as an agent of globalization in Nigeria but more specifically, we shall explore the following objectives

i. To examine how deregulation of broadcast media have affected the cultural heritage in Nigeria

ii. To examine how deregulation of broadcast media have affected the psychology of viewers in terms of multiple choices

\section{REWIEW OF RELATED LITERATURE}

This work is modeled through the path of social change theory proposed by Karl Marx in the $19^{\text {th }}$ century. He distinguished various development of production systems known as communism, ancient society, feudalism and capitalism [15]. Karl Marx has been described as the most famous Author who have tried to make the world understand that the carious ways that social organizations are put in place is determined to a great extent by factors of the economy and more specifically, industrial capitalism [2] The notion of industrial capitalism have given rise to competitive markets with its socioeconomic characteristics and these factors have positively affected the internally generated revenue from states as well as the GDP of nations.

In 1973, there was a huge disruption in of the country's political activities and the political class were at the verge making public every private investment. This led to the indigenization decree of 1973 which ensured the conversion of all internationally privately owned corporations to that of the state, in other words, the government was in total control of every economic activity [5] This was a result of the oil boom experienced within the 1970s and 1980s. The seed of deregulation was sown in Nigeria by section 39 of the 1979 constitution which stated that every person shall be entitled to own, establish and operate any medium for the dissemination of information [16] However, decree 38 which established the Nigerian broadcasting commission in August 1992 became the manifestation of the seed that was sown as through it, many private radio and television stations have been born in Nigeria [9] Despite the fact that government is still dominating the broadcast industry, we can say unequivocally that deregulation has catalyzed unprecedented level of broadcast proliferation in Nigeria.

Globalization according to O'Sullivan et al (1996) is the growth of cultural and economic network which operate on a worldwide basis and this has been facilitated the emergence of information and communication technology. Today, getting information has been made very easy as people can tune in to their television to see what is happening around the world. Moore and Lewis (2010) are of the opinion that economic globalization have gone through three main phases. The first was the known world globalization of the Roman empire, the second however is the $15^{\text {th }}$ and $16^{\text {th }}$ century globalization which was facilitated by Europeans and finally the third represents the post-world war II globalization. This present phase is witnessing a rapid global response through information and communication technology which has made the world become a global village.

\section{LIERATURE REVIEW AND OBJECTIVE OF THE STUDY}

In examining how deregulation of the broadcast media has affected the cultural heritage in Nigeria, [9] is of the opinion that Nigeria as a country have lost most of its cultural heritage sequel to the deregulation of broadcast media [4] Today, there is that enthusiasm among Nigerians to behave like Americans both in terms of their choice of language and dressing. Many Nigerians prefer the cultural and religious practices of developed countries. Christianity and Islam have also captured most of African cultures that even the children born in this generation do not know much practices of their home town [3] Broadcast media have really expanded the scope of religious activities and have made churches especially to increase membership over the years.

In looking at the psychological effect of indecision from the proliferation of stations, the quest for profit making among these stations have made them to expose contents which are supposed to have viewers discretion and there is always a huge challenge for viewers in terms of choosing the best station to view or listen to. Sometimes, other radio stations play music while the others are on head line news and this has affected the attention of teenagers from listening to information that would be of benefit to them. The television stations are not also left out as most of them prefer playing movies when others are broadcasting network news and it is very unfortunate to note that most viewers prefer movies instead of news [4]

\section{CONCEPTUAL FRAMEWORK}

The conceptual framework for this study is drawn from the works of [2] [12], [6], [9] and several authors who have extensively studied the developmental change in Nigeria through the act of deregulation as well as the pre-deregulation era. Their studies have enriched this work with valuable information relevant to the study of deregulation and how it has aided globalization in the Nigerian context while considering the broadcast media.

\section{BROADCASTING COMMISSION AND BROADCASTING IN NIGERIA}

After the establishment of the Nigerian Broadcasting Commission (NBC) in 1992, investors in the broadcast media industry who saw Nigeria as a potential market took advantage of the opportunity and today, the rate of competition going on between NTA, AIT, Channels, Sylverbird, wazobia, etc can never be overemphasized as they all want to give the very best to their customers at affordable rate. 
If we also consider the progress of Nollywood which was also named after American movie industry "Hollywood", we observe that over 2000 films are produced annually and this contributes significantly to GDP. Today, we have over 19 satellite and cable stations, over 90 radio stations and over 1000 TV stations in Nigeria [6] ; [4]. Although studies have pointed out the fact these rise in number of stations have its associated disadvantages and threats but the opportunities and strengths are far better.

\section{CONCLUSION}

There is no doubt that the broadcast media sub-sector of the economy has been one of those industries that have benefitted from the dividends of deregulation. Today, Nigeria is placed as one of those countries that globalization has greatly influenced. Thanks to the idea which emerged from General Ibrahim Babangida in 1986 and 1992, to General Adbusalami Abubakar who brought back the idea after it was neglected by the General Abacha's regime and thanks to Chief Olusegun Obasanjo who although didn't consider the idea during his military administration but pushed it further through the privatization of the communication sector as well as deregulation. Today, we can all say that we belong to an entity. Nigerians can now get information from anywhere in the world, they can now communicate with business partners, friends and loved once all over the world. They can also share and adapt cultures from anywhere in the world. This shows that deregulation has brought in more light into our dark country as we can boldly say that the broadcast media in Nigeria is the major driver of democracy in Nigeria especially with the passage of freedom of information bill.

\section{RECOMMENDATION}

Despite the numerous advantages posed by the broadcast media, there are still more potentials that are yet to be utilized within the industry and this is due to government persistent control of most of the media stations in Nigeria as well the Nigerian Broadcasting Commission which is also a regulatory agent. There is need for media independence from government so as to give relevant information to the general public rather than information that must be screened by government officials. There is also a problem of obsolete materials and methods used by most TV and radio stations especially those owned by government. Equipment used are over twenty years behind those used in developed countries. Therefore, there is a need for upgrade. Lastly, every station must have it as part of their vision to sell Nigerian cultural heritage to the world.

\section{REFERENCES}

[1] Anyanwu,J. C, Ejem, A. A and Nwokeocha, I. M., Deregulation, Globalisation and Current Issues in the Electronic Media in Nigeria," New Media and Mass Communication 41(1), pp. 14-24, 2015.
[2] Eregare, E. A., Values, Standards and Censorship: A Study of Nigeria Film and Video Censors Board (NFVCB), Nigeria: University of Ibadan, 2002.

[3] Eregare, E.A. \& Afolabi, A.O., "The Effects of Globalization and Deregulation on Nigerian Culture," Industries Journal of Social Sciences, 21(2), pp. 145-151, 2009.

[4] Giddens, A, The Consequences of Modernity, Cambridge: Polity Press, 1990.

[5] O'sullivan, T; Brains, D. \&Phillip, R., Studying the Media: An Introduction., London: Arnold, 1996.

[6] Adegbemile A.A, "Development of Telecommunications in Nigeria and its Impact on National Development: Experience From Around the World," Asian Journal of Information Technology 8(1), pp. 884- 890, 2007.

[7] Adoga O, "Critical Appraisal of Privatization in Nigeria,," 173 2011. [Online]. Available: http://www.hr.org/article.asp?id=5491.

[8] Salihu, A, "X-raying NBC," NBC News', Abuja, 2004.

[9] Momoh, T., Nigeria Media Laws,, Lagos: Efua Media Limited, 2002.

[10] Mohammed A, Oladipo K, Ahmed, A. S, Agabi, T. P, Adekalu, S. O, "Globalization and the challengees of National Development in Nigeria," International Journal of Humanities and Social Sciences Innovation 2(5), pp. 57-63, 2013.

[11] Albrow M, Globalization knowledge and Society, London: Sage Publications, 1990.

[12] Essay UK, "sociology/marx-webers-social-change," 05 02 2016. [Online]. Available: http://www.essay.uk.com/free-essays/sociology/marxwebers-social-change.php.

[13] Moore, K and Lewis, D. C, "Globalization and the Cold War: the communist dimension," Journal of management and organizational history 5(1), pp. 5-17, 2010.

[14] Dappa T.G and Daminabo D., "Deregulation of the nigerian economy :the theoretical milieu," in Proceedings of the 1st International Technology, Education and Environment Conference, 2011.

[15] Oketunmbi, E., "Gains and pains of liberalisation of broadcasting in nigeria: a critical assessment," Journal of communication and society, 1(3), pp. 1-10, 2007.

[16] Orunmoluyi, T. P., "Globalization: a millennium challenge for nigerian banks," The Economist 4(1), p. 31 $-32,2000$. 